\title{
USE OF MULTICRITERIA ANALYSIS AND GIS FOR SELECTING SITES FOR ONSHORE WIND FARMS: THE CASE OF ANDROS ISLAND (GREECE)
}

\author{
ATHINA BILI and DIMITRA G. VAGIONA* \\ Department of Spatial Planning and Development, Aristotle University of Thessaloniki, Thessaloniki, 54124, Greece \\ * Corresponding author: dimvag@plandevel.auth.gr
}

\begin{abstract}
Since wind power is one of the most promising sources of Renewable Energy (RES), the number of wind farms installed around the world is constantly increasing. The aim of this paper is to develop a mechanism for determining and evaluating the suitability of areas for siting wind farms, using a combination of Multi-criteria Data Analysis and Geographic Information Systems (GIS). This study was carried out on the island of Andros, Greece. The process involved a four-step gradual exclusion of unsuitable areas for siting wind farms and an evaluation of compatible areas using criteria both from this country's institutional framework and international literature. During the evaluation of available areas, using the Analytic Hierarchy Process (AHP), pairwise comparison is used in which the weightings were determined by a group of experts. Despite the very favourable wind conditions on Andros, only a small percentage of its total area was given a high score for siting wind farms, due to the strict constraints imposed. The proposed methodology for the optimum siting of wind parks can be used in any study area and at any planning scale (local, regional, national level).
\end{abstract}

Keywords: analytical hierarchy process; geographical information systems; Greece; onshore wind farm applications; site selection

\section{Introduction}

Energy is related to almost all human activities and forms an essential prerequisite for the economic and social development of a country. Ensuring an energy supply has resulted in numerous countries worldwide adopting renewable energy technologies.

Wind power is a form of renewable energy that is expected to be a widespread commercial success. According to experts' predictions, wind power could capture 5\% of the world energy market by the year 2020, if supported by superior economics and improved technologies (Lee 2009).

Wind power is developing at an extremely rapid pace around the world, while the siting of wind plants for its exploitation is a major issue and at the centre of a debate involving the international scientific community. This fact is reflected in the large number of scientific papers written on the subject of the siting of onshore wind parks at a global scale. The process of siting an electricity-producing plant, which runs on wind power, comprises a range of parameters described using environmental, social and economic data, which for its determination primarily requires the use of computing systems.

Geographic Information Systems (GIS) have proved to be a useful tool for estimating the potential of renewable energy regionally (Hoesen and Letendre 2010; Gil et al. 2011) and as a decision aiding tool in energy planning (Clarke and Grant 1996; Voivontas et al. 1998; Domingues and Amador 2007). Furthermore, the production of visualization maps in GIS has facilitated the contribution of researchers, policy makers, investors and citizens in the integrated renewable energy planning approach.
Numerous studies worldwide aim to evaluate compatible areas for the siting wind farms, by combining GIS with multi-criteria analysis (e.g. Kazim et al. 2015; Latinopoulos and Kechagia 2015; Watson and Hudson 2015; Höfer et al. 2016; Noorollahi et al. 2016). Although a variety of multi-criteria decision methods (MCDM) exist, a review of combined GIS-MCDM methods concludes that the AHP method is the most widely used technique in sustainable energy studies (Pohekar and Ramachandran 2004).

The aim of this paper is to create an integrated methodological approach for the identification and prioritization of the most suitable sites for wind farms on the island of Andros, in Greece. The specific study area was chosen due to the strong interest in siting wind farms on this particular island, mainly because the wind conditions there are very favourable. However, despite the large number of wind farms on this island, currently only one has an operating license, mainly because they are unacceptable to the local community on Andros.

In practice, the procedure for siting wind farms in Greece is most commonly based on an exclusion approach, which is based on the legal framework of the Special Framework for Spatial Planning and Sustainable Development for Renewable Energy (SFSPSD-RES) (SFSPSD-RES 2008). There are also some scientific studies (Voivontas et al. 1998; Tegou et al. 2010; Mourmouris and Potolias 2013; Xydis 2013; Tsoutsos et al. 2015; Latinopoulos and Kechagia 2015; Panagiotidou et al. 2016) that refer to Greece. The present study focuses on an island where despite the advantage of the wind potential, the deployment of wind farms raises strong social reactions.

This work reveals the state of the knowledge on the siting of onshore windfarms in order to improve the in- 
tegration of renewable energy into electricity generation. Scientific databases are investigated and the main issue addressed in terms of both exclusion and assessment are included in the analysis.

The present paper contributes to the existing literature on the deployment of onshore wind farms in various ways. GIS and AHP are integrated in order to develop a framework for selecting sites for wind turbines. GIS is used as a data extraction and measurement tool, while MCDA (AHP) serves as an evaluation tool. Existing renewable energy infrastructures as well as the minimum distance from such facilities are considered. Inadequate sites in terms of surface area are excluded from the analysis. Social acceptability is introduced as an evaluation criterion, while pairwise judgements were performed by the authors and local experts.

\section{Materials and Methods}

\section{Methodological framework for the selection of sites for wind farms}

The process of finding the optimum areas for siting wind farms in a geographical region includes various stages, which are determined by the researcher and do not follow any specific model. In this paper, a combination of applied methods is used, along with innovative elements and criteria. More specifically, at an initial stage, a four-step gradual exclusion of incompatible areas is adopted, based on a large number of criteria (exclusion criteria). Next, areas viewed as suitable are then further evaluated in the second stage, according to a number of criteria (evaluation criteria), while the process also takes into account the opinion of local experts by means of close ended questionnaires. Some of the exclusion criteria are also selected as evaluation criteria, mainly due to their importance and type (economic, environmental, social etc.); their selection is explained in detail below.

The stages and steps of the proposed method are shown in Fig. 1.

In the second stage, an evaluation of the potential areas resulting from the exclusion stage is carried out, in order to identify the optimum areas for siting wind farms on the island. The areas examined at this stage are all viewed as suitable, based primarily on the spatial planning criteria regarding wind farm installation. An attempt is then made to compare the areas available, in relation to technical, economic and social criteria. Within this framework, a multi-criteria analysis of the above-mentioned criteria is carried out, using the Analytic Hierarchy Process (Saaty 1980), whereby the weight of each criterion is determined by the authors and expert engineers from Andros. Upon completion of the Analytic Hierarchy Process, the areas with the highest suitability score for siting a wind farm are identified.

\section{Study area}

Andros is the northernmost island in the Cyclades in Greece and second in size to Naxos. It covers an area of $379.21 \mathrm{~km}^{2}$, with a total coastline of $176 \mathrm{~km}$ and a resident population of 10,000 people. It is located between Evoia and Tinos, at a distance of 6 and 1 nautical miles, respectively. It extends from northwest to southeast and has an elongated shape, with a maximum length of $40 \mathrm{~km}$ and a maximum width of $17 \mathrm{~km}$.

Andros is primarily mountainous, with verdant ravines, valleys and abundant surface and ground water. The largest part of the island (65\%) is covered by rural land, followed by forests and semi-natural areas covering $34 \%$, while artificial surfaces only cover about $1 \%$ of the island's total area.

Andros is windy since most of the island experiences winds of $8-10 \mathrm{~m} / \mathrm{s}$ or even higher than $10 \mathrm{~m} / \mathrm{s}$. The only exception is the northern and central part of the island, where the wind speed in certain areas is approximately $7-8 \mathrm{~m} / \mathrm{s}$ and in a very few places it does not exceed $5 \mathrm{~m} / \mathrm{s}$.

Regarding other sources of Renewable Energy according to the Regulatory Authority for Energy, there are no geothermal, solar thermal, small hydroelectric, hybrid or biomass plants on the island of Andros. Permission to build a photovoltaic plant in the northern part of the island was rejected, and there is one wind farm operating on the island.

\section{Stage 1/ Step 1: Exclusion areas}

According to Article 6 of the Special Framework for SFSPSD-RES (SFSPSD-RES 2008) and the existing infrastructure and areas in Andros, the areas considered incompatible as regards the installation of wind farms, which are excluded from the outset, are the following:

- point areas: ports, heliport, bathing areas, archaeological sites, listed cultural monuments, monasteries, antennae;

- linear areas: the road network and high-voltage electricity grid;

- extensive areas: Sites of Community Importance (SCIs) and Special Protection Areas (SPAs) of the Natura 2000 network, Areas of Outstanding Natural Beauty (AONBs), settlements, highly productive farmland, quarries and mines.

In addition, the relevant planning also excludes rivers and lakes, i.e. surface water bodies, since it is not possible to site an onshore wind farm within them, (e.g. Bennui et al. 2007; Nguyen 2007; Aydin et al. 2010; Phuangpornpitak and Tia 2011; Zhou et al. 2012). According to the literature, the planning also excludes Wildlife Refuges (Aydin et al. 2010; Watson and Hudson 2015), which are not included in the Special Framework, but are nevertheless considered to be very important for preserving the biodiversity of a region, since it is thought that if wind 


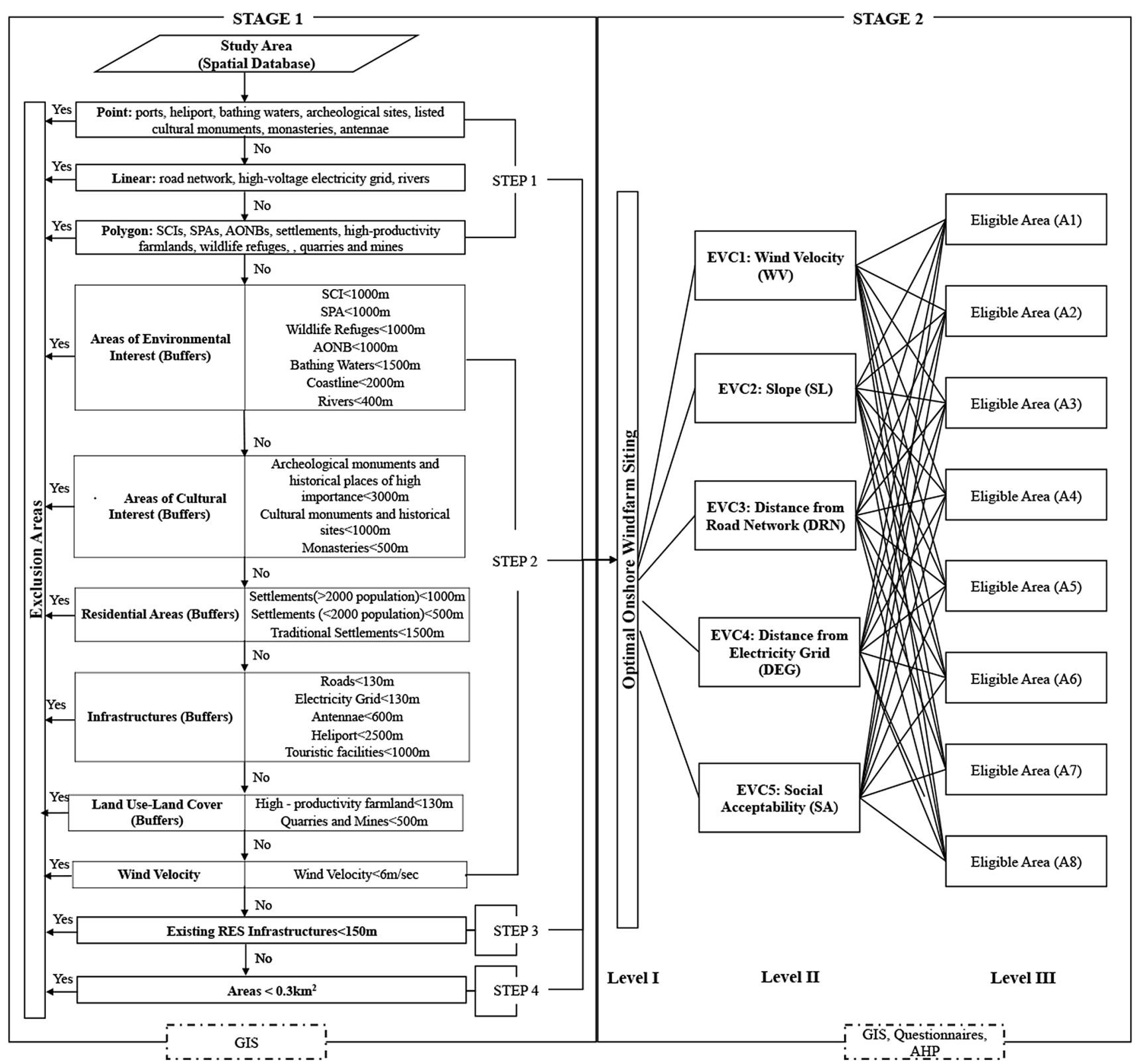

Fig. 1 Flow diagram of the method used.

turbines are installed therein, then this will potentially disrupt the relevant ecosystem.

\section{Stage 1/ Step 2: Incompatibility zones}

In order to determine the minimum distances from excluded areas and incompatibility zones for siting wind farms, the relevant national legislation is taken into account, i.e. SFSPSD-RES (SFSPSD-RES 2008), as well as the distances mentioned in international literature.

Table 1 lists the criteria included in the present analysis.

\section{Stage 1/ Step 3: Existing RES infrastructures}

After excluding the incompatible areas and setting the minimum distances in Table 1, the most suitable areas for the siting of wind parks are identified. Nevertheless, these specific areas may include some already used for
RES infrastructure, which either are in operation or have a production license, an installation license, are undergoing assessment or have been rejected. For this reason, at this stage, the present study excludes all areas used for existing RES facilities, and obviously parts of these that may exist within the areas deemed suitable for siting wind farms in the previous stage.

In addition, the SFSPSD-RES (SFSPSD-RES 2008) defines a distance of $2.5 \mathrm{~d}$ ( $\mathrm{d}$ is the diameter of the wind turbine's rotor, which is equal to $85 \mathrm{~m}$ ) from other RES facilities of the same technology, in order to safeguard the functionality and performance of wind parks. Therefore, at this stage of the present study, there is a recommended buffer zone at $215 \mathrm{~m}$ around any existing operational wind facilities, and obviously those located within the areas that were deemed suitable for siting wind farms in the previous stage. 
Table 1 Exclusion Criteria Restrictions.

\begin{tabular}{|c|c|c|c|c|c|}
\hline $\begin{array}{l}\text { Main } \\
\text { categories }\end{array}$ & A/A & Exclusion Criteria & $\begin{array}{l}\text { Buffer zones } \\
\text { SFSPSD-RES } \\
(\mathrm{d}=85 \mathrm{~m})\end{array}$ & $\begin{array}{l}\text { Buffer zones } \\
\text { Literature review (mode value) }\end{array}$ & $\begin{array}{l}\text { Buffer zones } \\
\text { Present study }\end{array}$ \\
\hline \multirow{6}{*}{$\begin{array}{l}\text { Areas of } \\
\text { environmental } \\
\text { interest }\end{array}$} & 1 & $\begin{array}{l}\text { Sites of Community } \\
\text { Importance (SCls) }\end{array}$ & - & $\begin{array}{c}1000 \text { m (Baban 2001; Aydin et al. 2010; Effat 2014; Wang } \\
\text { et al. 2014; Latinopoulos and Kechagia 2015; Watson and } \\
\text { Hudson 2015) }\end{array}$ & $1000 \mathrm{~m}$ \\
\hline & 2 & $\begin{array}{l}\text { Special Protection } \\
\text { Areas (SPAs) }\end{array}$ & - & $\begin{array}{c}1000 \mathrm{~m} \text { (Baban 2001; Aydin et al. 2010; Effat 2014; Wang } \\
\text { et al. 2014; Latinopoulos and Kechagia 2015; Watson and } \\
\text { Hudson 2015) }\end{array}$ & $1000 \mathrm{~m}$ \\
\hline & 3 & Wildlife Refuges & - & $\begin{array}{c}1000 \mathrm{~m} \text { (Baban 2001; Aydin et al. 2010; Effat 2014; Wang } \\
\text { et al. 2014; Latinopoulos and Kechagia 2015; Watson and } \\
\text { Hudson 2015) }\end{array}$ & $1000 \mathrm{~m}$ \\
\hline & 4 & $\begin{array}{l}\text { Areas of Outstanding } \\
\text { Natural Beauty } \\
\text { (AONBs) }\end{array}$ & - & $\begin{array}{c}1000 \mathrm{~m} \text { (Baban 2001; Aydin et al. 2010; Effat 2014; Wang } \\
\text { et al. 2014; Latinopoulos and Kechagia 2015; Watson and } \\
\text { Hudson 2015) }\end{array}$ & $1000 \mathrm{~m}$ \\
\hline & 5 & Bathing areas & $1500 m$ & - & $1500 m$ \\
\hline & 6 & Coastline & - & 2000 m (Effat 2014) & $2000 \mathrm{~m}$ \\
\hline Water Bodies & 7 & Rivers & - & $\begin{array}{l}400 \text { m (Baban and Parry 2001; Nguyen 2007; Tegou et al. } \\
\text { 2007; Aydin et al. 2010; Zhou et al. 2012) }\end{array}$ & $400 \mathrm{~m}$ \\
\hline \multirow{3}{*}{$\begin{array}{l}\text { Areas of } \\
\text { Cultural } \\
\text { Interest }\end{array}$} & 8 & $\begin{array}{l}\text { Archaeological } \\
\text { monuments and } \\
\text { historical places } \\
\text { of high importance }\end{array}$ & $3000 \mathrm{~m}$ & 3000 m (Xydis 2013; Tsoutsos et al. 2015) & $3000 \mathrm{~m}$ \\
\hline & 9 & $\begin{array}{l}\text { Cultural monuments } \\
\text { and historical sites }\end{array}$ & $7 d(600 m)$ & $\begin{array}{l}1000 \mathrm{~m} \text { (Baban and Parry 2001; Tegou et al. 2007; Effat } \\
\text { 2014) }\end{array}$ & $1000 \mathrm{~m}$ \\
\hline & 10 & Monasteries & $500 \mathrm{~m}$ & 500 m (Hansen 2005; Tegou et al. 2010; Tsoutsos et al. 2015) & $500 \mathrm{~m}$ \\
\hline \multirow{3}{*}{$\begin{array}{l}\text { Residential } \\
\text { Areas }\end{array}$} & 11 & $\begin{array}{l}\text { Settlements }>2000 \\
\text { population }\end{array}$ & $1000 \mathrm{~m}$ & $\begin{array}{l}1000 \mathrm{~m} \text { (Ouammi et al. 2012; Gass et al. 2013; Tsoutsos et } \\
\text { al. 2015) }\end{array}$ & $1000 \mathrm{~m}$ \\
\hline & 12 & $\begin{array}{l}\text { Settlements }<2000 \\
\text { population }\end{array}$ & $500 \mathrm{~m}$ & $\begin{array}{l}500 \text { m (Tegou et al. 2010; Phuangpornpitak and Tia 2011; } \\
\text { Zhou et al. 2012; Tsoutsos et al. 2015; Noorollahi et al. 2016) }\end{array}$ & $500 \mathrm{~m}$ \\
\hline & 13 & $\begin{array}{l}\text { Traditional Settle- } \\
\text { ments }\end{array}$ & $1500 \mathrm{~m}$ & $\begin{array}{c}1500 \text { m (Tegou et al. 2010; Xydis 2013; Tsoutsos et al. 2015; } \\
\text { Latinopoulos and Kechagia 2015) }\end{array}$ & $1500 \mathrm{~m}$ \\
\hline \multirow{4}{*}{ Infrastructure } & 14 & Roads & $1.5 \mathrm{~d}(130 \mathrm{~m})$ & $\begin{array}{c}500 \text { m (Bennui et al. 2007; Effat 2014; Kazim et al. 2015; } \\
\text { Noorollahi et al. 2015) }\end{array}$ & $130 \mathrm{~m}$ \\
\hline & 15 & Electricity Grid & $1.5 \mathrm{~d}(130 \mathrm{~m})$ & 250 m (Effat 2014; Kazim et al. 2015; Noorollahi et al. 2015) & $130 \mathrm{~m}$ \\
\hline & 16 & Antennae/Radar & - & 600 m (Lejeune and Kazim 2015) & $600 \mathrm{~m}$ \\
\hline & 17 & Airports & - & $\begin{array}{l}2500 \text { m (Voivontas et al. 1998; Nguyen 2007; Aydin et al. } \\
\text { 2010; Ouammi 2012; Wang et al. 2014; Noorollahi 2016) }\end{array}$ & $2500 \mathrm{~m}$ \\
\hline \multirow{3}{*}{$\begin{array}{l}\text { Land } \\
\text { Use - Land } \\
\text { Cover }\end{array}$} & 18 & $\begin{array}{l}\text { Tourism-related } \\
\text { facilities }\end{array}$ & $1000 \mathrm{~m}$ & $\begin{array}{c}1000 \text { m (Bennui et al. 2007; Xydis 2013; Tsoutsos et al. 2015; } \\
\text { Latinopoulos and Kechagia 2015) }\end{array}$ & $1000 \mathrm{~m}$ \\
\hline & 19 & $\begin{array}{l}\text { High-productivity } \\
\text { farmland }\end{array}$ & $1.5 \mathrm{~d}(130 \mathrm{~m})$ & - & $130 \mathrm{~m}$ \\
\hline & 20 & Quarries and Mines & $500 \mathrm{~m}$ & $500 \mathrm{~m}$ (Xydis 2013; Tsoutsos et al. 2015) & $500 \mathrm{~m}$ \\
\hline Wind Velocity & 21 & Wind Velocity & - & $\begin{array}{c}6 \mathrm{~m} / \mathrm{s} \text { (Voivontas et al. 1998; Wang et al. 2014; Höfer et al. } \\
\text { 2016) }\end{array}$ & $6 \mathrm{~m} / \mathrm{s}$ \\
\hline
\end{tabular}

\section{Stage 1/ Step 4: Carrying capacity restrictions}

Next, and after excluding the areas with an existing RES infrastructure and areas neighbouring on operational wind facilities, and in order to complete the exclusion process, we excluded areas that are too small. More specifically, in the framework of this paper, since the exclusion of the above areas takes place in an ArcMap environment, it is possible that polygonal shapes may occur, which may full fill all the set criteria, but are nevertheless too small, which means that installing wind turbines on this land is either impossible or economically non-via- ble. For this reason, this paper excludes areas that are less than $300,000 \mathrm{~m}^{2}$ or $0.3 \mathrm{~km}^{2}$ in size.

\section{Stage 2: Evaluation criteria}

The exclusion criteria, the selection of which is described above, primarily aim at protecting the environmental and cultural background of the area studied and to strictly uphold the safety distances set by the current legislation. It is therefore deemed necessary that the evaluation criteria used in the process of defining suitable areas for the siting of wind parks aim at ensuring that the 
project is cost effective, construction costs are minimized and the project meets with the least possible reaction from the people of Andros. For this purpose, five evaluation criteria were selected, which include: EVC1: Wind Velocity (WV), EVC2: Slope (SL), EVC3: Distance from Road Network (DRN), EVC4: Distance from Electricity Grid (DEG) and EVC5: Social Acceptability (SA). Taking into consideration the fact that the construction of a large number of wind parks was suspended on Andros due to reactions from the local community, it was deemed essential to include the last of the above criteria in the present study. For this purpose, a questionnaire was addressed to expert engineers, who either live on or come from Andros, asking them to give a rating to the eight potential areas, resulting from the previous stage of the study (Stage 1). Their rating involved the level of social acceptance they believed would be given for the installation of a wind park in each of these eight areas. In addition, the feelings of the local communities were also included in the evaluation, as recorded by the daily local press.

All the evaluation criteria are presented in Table 2 and described in detail below.

\section{Results and Discussion}

In the following sub-section, the results of the present study are presented and discussed. Initially, unsuitable sites for the deployment of onshore windfarms are presented along with the potential/eligible areas, which are candidates for further evaluation (Stage I of the proposed framework, Fig. 1). Next, the results of the AHP application (Stage II of the proposed framework, Fig. 1) are shown and the most adequate areas for the siting of onshore windfarms on Andros Island are determined.

\section{Exclusion of unsuitable areas}

Areas that were excluded due to incompatibility, include ports, the heliport, bathing areas, listed cultural monuments, monasteries, telecommunication antennae, road network and electricity grid, SCIs and SPAs of the
Natura 2000 network, Wildlife Refuges, AONBs, settlements and highly productive farmland. The excluded areas (Step 1 - Stage 1) are presented in Fig. 2.

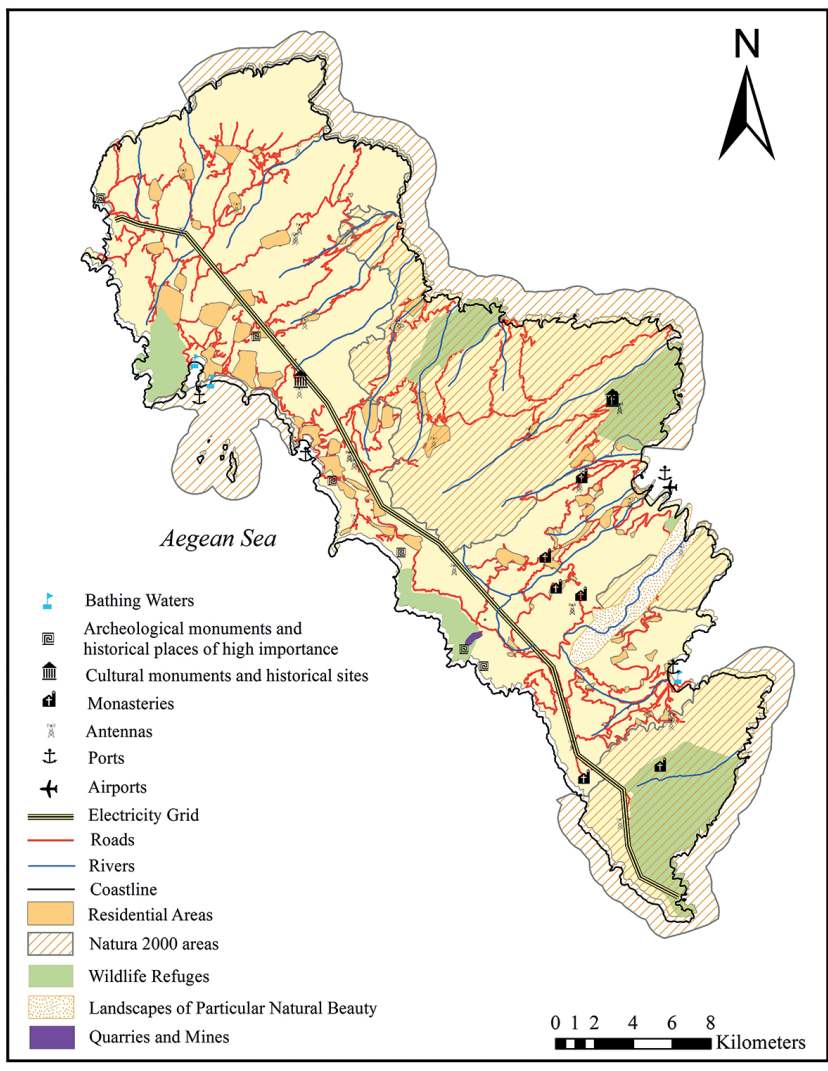

Fig. 2 Excluded areas.

\section{Definition of eligible areas}

Next, the minimum distances presented in Table 1 are applied, which in Step 2 - Stage 1 results in the following available areas (Fig. 3).

Step 3 - Stage 1 of the methodology, involves the exclusion of parts of the available areas where RES facilities are already in place. Finally, in Step 4 - Stage 1, polygonal areas smaller than $0.3 \mathrm{~km}^{2}$ are excluded.

The set of eligible areas that are candidates for siting wind farms and further evaluation are presented in Fig. 4, while Table 3 includes their surface area.

Table 2 Evaluation Criteria.

\begin{tabular}{|l|l|l|}
\hline Criteria & Type & Description \\
\hline EVC1: Wind Velocity (WV) (m/s) & Economic/Technical & $\begin{array}{l}\text { The greater the wind velocity in an area the more electricity will } \\
\text { be produced in that area }\end{array}$ \\
\hline EVC2: Slope (SL) (\%) & Technical/Economic & $\begin{array}{l}\text { The greater the slope of an area the higher the construction costs } \\
\text { in that area }\end{array}$ \\
\hline $\begin{array}{l}\text { EVC3: Distance from Road Network (DRN) } \\
\text { (m) }\end{array}$ & Economic & $\begin{array}{l}\text { The greater the distance of an area from the road network the } \\
\text { higher the construction and installation costs }\end{array}$ \\
\hline $\begin{array}{l}\text { EVC4: Distance from Electricity Grid (DEG) } \\
\text { (m) }\end{array}$ & Economic & $\begin{array}{l}\text { The greater the distance of an area from the EG network the } \\
\text { higher the construction and production costs }\end{array}$ \\
\hline \begin{tabular}{l} 
EVC5: Social Acceptability (SA) \\
\hline
\end{tabular} & Social & $\begin{array}{l}\text { The higher the level of acceptance in an area the easier it will be } \\
\text { to construct an RES without a social reaction }\end{array}$ \\
\hline
\end{tabular}




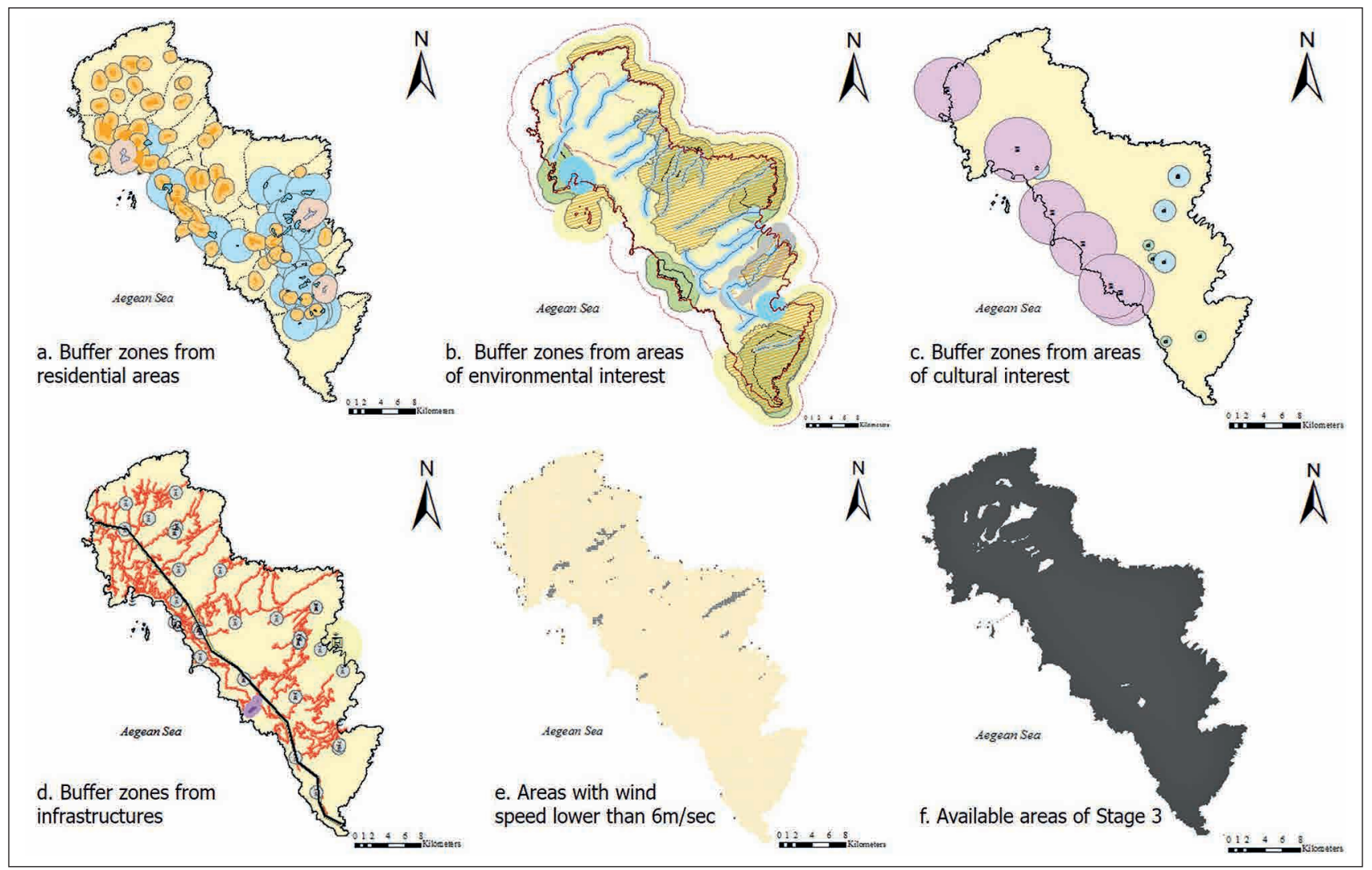

Fig. 3 (a) Buffer zones around areas of environmental interest, (b) areas of cultural interest, (c) residential areas, (d) infrastructures, (e) areas with a wind velocity lower than $6 \mathrm{~m} / \mathrm{s}$ and (f) suitable areas of land.

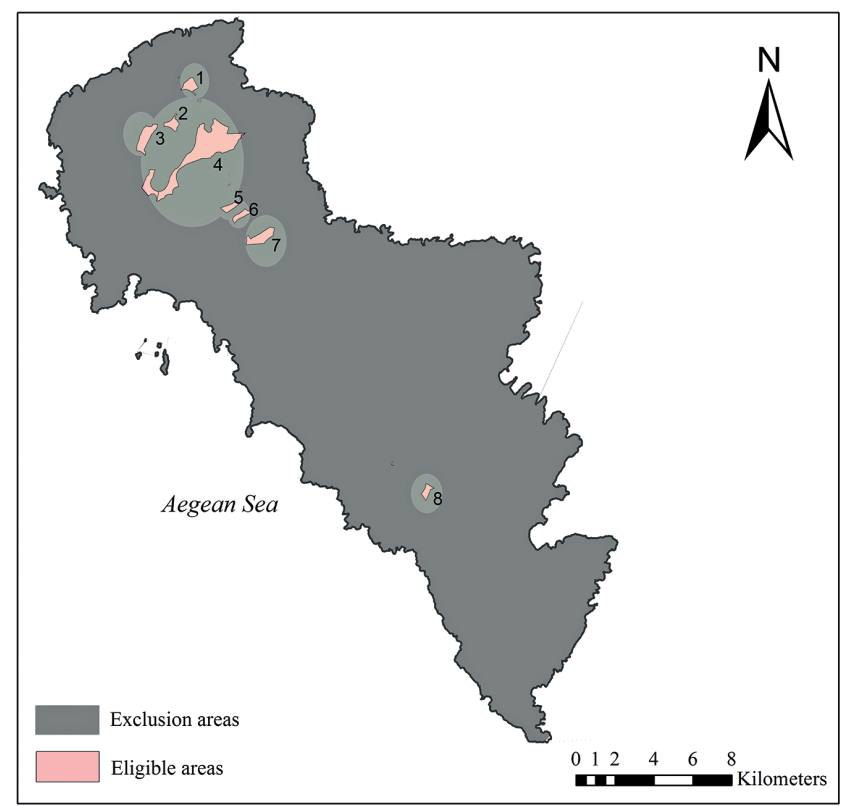

Fig. 4 Candidates areas for the siting of wind farms - areas for evaluation.

Table 3 Surface of eligible areas.

\begin{tabular}{|l|c|}
\hline Area & Size $\left.\mathbf{( k m}^{\mathbf{2}}\right)$ \\
\hline $\mathbf{1}$ & 0.556112 \\
\hline $\mathbf{2}$ & 0.453393 \\
\hline $\mathbf{3}$ & 1.072405 \\
\hline $\mathbf{4}$ & 6.718209 \\
\hline
\end{tabular}

\begin{tabular}{|l|c|}
\hline $\mathbf{5}$ & 0.35339 \\
\hline $\mathbf{6}$ & 0.355856 \\
\hline $\mathbf{7}$ & 0.964385 \\
\hline $\mathbf{8}$ & 0.337122 \\
\hline Total & $\mathbf{1 0 . 2 0 8}$ \\
\hline
\end{tabular}

\section{Evaluation and hierarchical ranking of eligible areas}

\section{Quantification of the relative weights of evaluation criteria}

In Table 4, the pairwise comparison of the evaluation criteria is presented, as formulated by the expert group (authors and experts) within the framework of a more objective rating of the evaluation criteria.

Table 4 Pairwise comparison matrix of evaluation criteria $\mathrm{Ci}, \mathrm{i}=1-5$ with respect to the objectives.

\begin{tabular}{|l|c|c|c|c|c|}
\hline & $\begin{array}{c}\text { EVC1 } \\
(\mathrm{WV})\end{array}$ & $\begin{array}{c}\text { EVC2 } \\
(\mathrm{SL})\end{array}$ & $\begin{array}{c}\text { EVC3 } \\
(\mathrm{DRN})\end{array}$ & $\begin{array}{c}\text { EVC4 } \\
(\mathrm{DEG})\end{array}$ & $\begin{array}{c}\text { EVC5 } \\
(\mathrm{SA})\end{array}$ \\
\hline EVC1 (WV) & 1 & 3 & 3 & 3 & $1 / 5$ \\
\hline EVC2 (SL) & $1 / 3$ & 1 & 1 & 1 & $1 / 7$ \\
\hline EVC3 (DRN) & $1 / 3$ & 1 & 1 & 1 & $1 / 7$ \\
\hline EVC4 (DEG) & $1 / 3$ & 1 & 1 & 1 & $1 / 7$ \\
\hline EVC5 (SA) & 5 & 7 & 7 & 7 & 1 \\
\hline
\end{tabular}

European Journal of Environmental Sciences, Vol. 8, №. 1 
From the above matrix and the pairwise comparison, it is clear that wind velocity is slightly more important (3) than the slope, the distance from the road network and from the electricity grid, but less important (1/5) than social acceptance. Furthermore, the slope is judged as equally important to the distance from the road network and the electricity grid, but slightly less important than wind velocity (1/3) and far less important than social acceptance $(1 / 7)$. The rest of the criteria have exactly the same relation to the distance from the road network and the electricity grid. Finally, social acceptance is viewed as much more important (5) than wind velocity and far more important than the other three criteria.

The priority of each criterion is presented in Fig. 5.

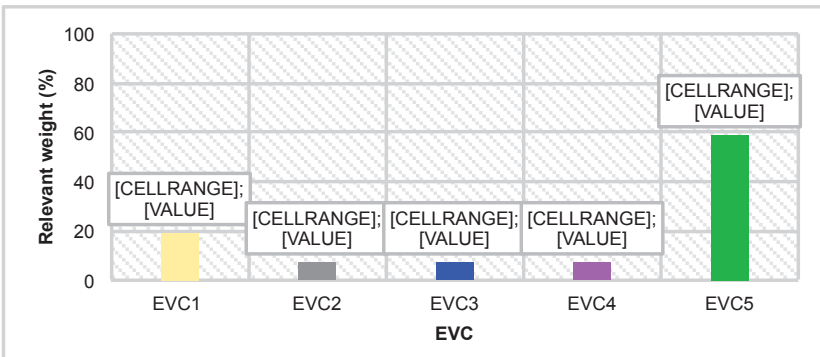

Fig. 5 Relevant weights of evaluation criteria $\mathrm{Ci}, \mathrm{i}=1-5$ with respect to the objective.

The judgments are consistent since CR is equal to 0.01 , which is lower than the threshold of 0.1 .

\section{Evaluation and ranking of eligible areas}

Next, and following the pairwise comparison of the criteria and calculation of their priorities, the pairwise comparison of the elements at the second level follows (Fig. 1), i.e. of the available areas compared to the elements of the first level, namely the criteria. Thus, the eight (8) areas available for siting a wind park are compared with one another, as regards the five (5) evaluation criteria, i.e. wind velocity, slope, distance from road network, distance from electricity grid and social acceptance.

It should be noted that the judgments related to the five pairwise comparison matrices are characterized by adequate accuracy, since the pairwise comparisons have been performed either by using the GIS thematic maps, which are related to the evaluation criteria EVC1 $\sim$ EVC4 or by considering the expertise of locals (EVC5). One engineer and one planner who lives on the island were interviewed and asked to evaluate each site in terms of social acceptability. In addition, the calculation of $\mathrm{CR}$ values below 0.1 for all matrices enhances their consistency. The relevant weights of the five priority vectors are shown in Fig. 6.

As can be seen for area A8, which is located in the southern part of the island and comes first for wind velocity, followed by the other areas with much lower scores. The lowest score corresponds to area A6, for which the wind velocities recorded in its interior are lower.

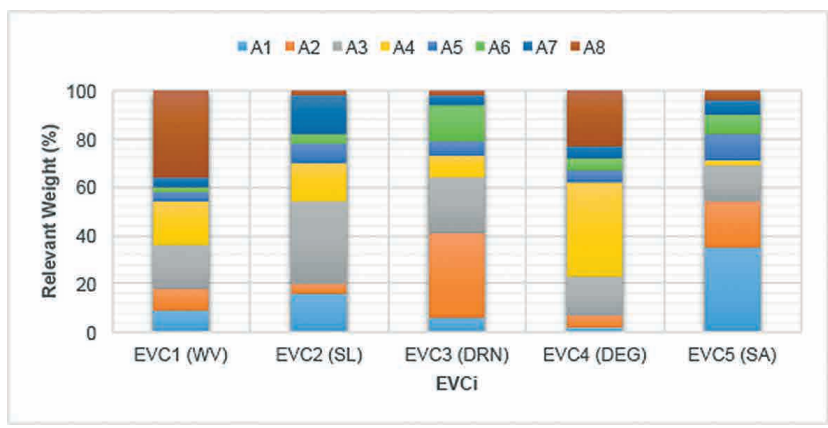

Fig. 6 Relevant weights of decision alternatives $A m, m=1, \ldots, 8$ with respect to $E V C i, i=1-5$.

In terms of the slope, area $\mathrm{A} 3$, which is located in the northern part of the island, is top in the ranking, followed at a great distance by the other areas. Areas A6, A2 and $A 8$ are the lowest in the ranking, since their slopes at some points reach $20-25 \%$.

In terms of the distance from the road network, areas A7 and A8 are last, since they do not have access to any part of the island's road network, although they are located very close to various roads. Area A2 is top in the ranking.

Area A4, which is the westernmost of all available areas, and is closest to the electricity grid, comes top in the ranking; then, depending on how far to the east the available areas lie, the lower they are ranked, since the electricity grid extends over the western part of Andros.

Area A1, in the north of the island, is considered to be the one with the highest level of social acceptance, while A4 ranks last.

\section{Conclusions}

The present study is an integrated proposal for the siting of onshore wind parks that can be used both in Greece and worldwide. It is applied to the island of Andros that is in the South Aegean, which is a windy area based on Geographic Information Systems (GIS) depicting the data from a Multicriteria Analysis for the evaluation of the suitability of relevant areas.

The extensive literature review and thorough research into the Greek institutional framework, which comprises the Special Framework of Spatial Planning and Sustainable Development for Renewable Energy Sources, have been used to formulate the exclusion and evaluation criteria, which were included in this study. The basic objective for the selection of the criteria is the correct siting of a wind park in order to limit and avoid any effect that such actions may cause on a small island such as Andros, where a limited social acceptance of similar projects has occurred.

The application of the criteria is realized using the methodology proposed in this paper and consists of distinct stages. One stage prior to the evaluation is the exclusion of incompatible siting areas, on the basis of particu- 
larly strict criteria, mainly spatially related, which aim to uphold safety considerations, environmental protection and the specifications of the Greek institutional framework. In order to evaluate those areas deemed suitable, criteria are selected that aim to reduce the construction and maintenance costs of the wind farms, and increase the acceptance of the project by the local community and its economic efficiency. It is therefore considered important to include the criterion of social acceptance in this study, which is evaluated using the opinion of expert engineers and reports of the opinion of the local society of Andros in the daily press.

The results of the application of this methodology for Andros are of particular interest, since the areas that emerge as being suitable for the siting of wind parks are primarily located in the northern part of the island, where the largest concentration of proposals for wind plants are located. The areas with the highest scores, that are most suitable, are those adjacent to an existing wind plant. This knowledge could be used as the subject for a debate and of further research into their future unification, so that larger amounts of energy could potentially be produced that would ensure the energy autonomy of the island of Andros.

The present study helps promote the vision of a sustainable energy production, which makes use of the comparative advantages of certain areas, while also supporting the energy policies recommended by the European Union, which aim at sustainability. The recommended methodology is applicable to other islands where the geographical restrictions and exclusion criteria are similar due to spatial characteristics. Furthermore, the stages in the methodological framework can be applied by either readjusting or maintaining the said exclusion and evaluation criteria for any study area or any planning scale (local, regional, national level) depending on data availability and policy priorities.

\section{REFERENCES}

Aydin N, Kentel E, Duzgun S (2010) GIS-based environmental assessment of wind energy systems for spatial planning: A case study from Western Turkey. Renew Sustain Energy Rev 14: 364-373.

Baban SMJ, Parry T (2001) Developing and applying a GIS-assisted approach to locating wind arms in the UK. Renew Energy 24: 59-71.

Bennui A, Rattanamanee P, Puetpaiboon U, Phukpattaranont P, Chetpattananondh K (2007) Site selection for large wind turbine using GIS. In: Proceedings of the PSU-UNS International Conference on Engineering and Environment (ICEE 2007), Phuket, Thailand, 2007 May 10-11.

Clarke JA, Grant AD (1996) Planning support tools for the integration of renewable energy at the regional level. Renew Energy 9: 1090-1093.

Domingues J, Amador J (2007) Geographical information systems applied in the field of renewable energy sources. Comput Ind Eng 52: 322-326.
Effat H (2014) Spatial Modeling of Optimun Zones for Wind Farms Using Remote Sensing and Geographic Information System, Application in the Red Sea, Egypt. ISPRS Int J Geo-Inf 6: 358-374.

Gass V, Schmidt J, Strauss F, Schmid E (2013) Where the wind blows: Assessing the effect of fixed and premium based feedin tariffs on the spatial diversification of wind turbines. Energ Policy 53: 323-30.

Gil MV, Blanco D, Carballo MT, Calvo LF (2011) Carbon stock estimates for forest in the Gastilla y Leon Region, Spain. A GIS based method for evaluation spatial distribution of residual biomass for bio-energy. Biomass Bioenerg 35: 243-252.

Hansen HS (2005) GIS-based multi-criteria analysis of wind farm development. In: Proceedings of the 10th Scandinavian Research Conference on Geographical Information Science (ScanGis 2005), Stockholm, Sweden, 2005 June 13-15.

Hoesen JV, Letendre S (2010) Evaluating potential renewable energy resources in poultney, vermont: A GIS-based approach to supporting rural community energy planning. Renew Energy 35: 2114-2122.

Höfer T, Sunak Y, Siddique H, Madlener R (2016) Wind farm siting using a spatial Analytic Hierarchy Process approach: A case study of the Städteregion Aachen. Appl Energy 163: 222-243.

Kazim B, Simsek A, Aydin U, Tosun M (2015) A GIS-based Multiple Criteria Decision Analysis approach for wind power plant site selection. Util Policy 37: 86-96.

Latinopoulos D, Kechagia K (2015) A GIS-based multi-criteria evaluation for wind farm site selection. A regional scale application in Greece. Renew Energy 78: 550-60.

Lee AHI, Chen HH, Kang HY (2009) Multi-criteria decision making on strategic selection of wind farms. Renew Energy 34: 20-126.

Lejeune P, Feltz C (2008) Development of a decision support system for setting up a wind energy policy across the Walloon Region (southern Belgium). Renew Energy 33: 2416-22.

Mourmouris JC, Potolias C (2013) A multi-criteria methodology for energy planning and developing renewable energy sources at a regional level: a case study Thassos, Greece. Energ Policy 52: $522-30$.

Nguyen KQ (2007) Wind energy in Vietnam: resource assessment, development status and future implications. Energ Policy 35: 1405-13.

Noorollahi Y, Yousefi H, Mohammadi M (2016) Multi-criteria decision support system for wind farm site selection using GIS. Sustainable Energy Technologies and Assessments 13: 38-50.

Ouammi A, Ghigliotti V, Robba M, Mimet A, Sacile R (2012) A decision support system for the optimal exploitation of wind energy on regional scale. Renew Energy 37: 299-309.

Panagiotidou M, Xydis G, Koroneos C (2016) Environmental Siting Framework for Wind Farms: A Case Study in the Dodecanese Islands. Resour 5: 24.

Phuangpornpitak N, Tia S (2011) Feasibility Study of Wind Farms Under the Thai very small Scale Renewable Energy Power Producer (VSPP) Program. Energy Proced 9: 159-170.

Pohekar SD, Ramachandran M (2004) Application of multi-criteria decision making to sustainable energy planning-A review. Renew Sustain Energy Rev 8: 365-81.

Saaty TL (1980) The analytic hierarchy process. McGraw-Hill. New York.

SFSPSD-RES (2008) Special framework for spatial planning and sustainable development for renewable energy resources. (OGG2464B'/2008). http:// www.minenv.gr/4/42/00/KYA.APE .January.2008.pdf; 2008. Accessed on 2 May 2017.

Tegou LI, Polatidis H, Haralambopoulos DA (2007) Distributed Generation with Renewable Energy Systems: The spatial di- 
mension for an autonomous Grid. In: Proceedings of the 47th conference of the European Regional Science Association, Local governance and sustainable development, Paris, France, August 29 - September 2007.

Tegou LI, Polatidis H, Haralambopoulos DA (2010) Environmental management framework for wind farm siting: methodology and case study. J Environ Manag 91: 2134-47.

Tsoutsos T, Tsitoura I, Kokologos D, Kalaitzakis K (2015) Sustainable siting process in large wind farms case study in Crete. Renew Energy 75: 474-80.

Voivontas D, Assimacopoulos D, Mourelatos A, Corominas J (1998) Evaluation of renewable energy potential using a GIS decision support system. Renew Energy 13: 333-44.
Wang Q, Mwirigi M, Kinoshita I (2014) A GIS-Based Approach in Support of Spatial Planning for Renewable Energy: A Case Study of Fukushima, Japan. Sustain 6: 2087-2117.

Watson JJ, Hudson MD (2015) Regional scale wind farm and solar farm suitability assessment using GIS-assisted multi-criteria evaluation. Landscape Urban Plan 138: 20-31.

Xydis G (2013) A techno-economic and spatial analysis for the optimal planning of wind energy in Kythira island, Greece. Int J Prod Econ 146: 440-452.

Zhou Y, Zhang B, Zou J, Bi J, Wang K (2012) Joint R\&D in low-carbon technology development in China: A case study of the wind-turbine manufacturing industry. Energ Policy 46: 100-108. 